\title{
Antiviral Efficacy of an Aquatic Disinfectant Tablet Composed of Calcium Hypochlorite Against Viral Hemorrhagic Septicemia Virus
}

\author{
Eun-Kee Park*, Eun-Ah Yu**, Chun-Nam Cha ${ }^{* * *}$, Chang-Yeul Yoo****, \\ Hyunju Choi*****, Suk Kim, and Hu-Jang Lee ${ }^{\dagger}$ \\ Research Institute of Life Sciences, College of Veterinary Medicine, Gyeongsang National University, \\ Chinju 600-701, Korea \\ *Department of Medical Humanities and Social Medicine, College of Medicine, Kosin University, \\ Busan 602-703, Korea \\ **Tongyeong National Quarantine Station, Ministry of Health \& Welfare, Tongyeong 650-110, Korea \\ ***Engineering Research Institute, Department of Industrial Systems Engineering, \\ Gyeongsang National University, Chinju 600-701, Korea \\ ****Department of Computer Information, Gyeongnam Provincial Namhae College, Namhae 668-801, Korea \\ *****Elderly Life Redesign Institute, Department of Biomedical Laboratory Science, \\ Inje University, Gimhae 621-749, Korea
}

\begin{abstract}
Objectives: The objectives of this study were to identify the virucidal efficacy against the viral hemorrhagic septicemia virus (VHSV) of an aquatic disinfectant tablet composed of calcium hypochlorite.

Methods: Virucidal efficacy was determined through the viability of VHSV contacted with the disinfectant in a viral stock cultured in a fathead minnow cell line. An aquatic disinfectant tablet and VHSV were reacted under distilled water (DW), hard water (HW) or organic matter suspension (OM) conditions.

Results: Under DW and HW conditions, VHSV was inactivated with 24,000- and 2000-fold dilutions of the aquatic disinfectant tablet, respectively. With the investigation of the antiviral effect of the disinfectant under OM conditions, VHSV was inactivated with a 16,000-fold dilution of the aquatic disinfectant tablet.

Conclusions: The results from this study showed that the aquatic disinfectant tablet was a highly effective disinfectant against VHSV. In the future, a controlled field trial is required to determine whether the use of an aquatic disinfectant tablet will be able to reduce VHSV in a cultured marine fish farm.
\end{abstract}

Keywords: Aquatic disinfectant tablet, viral hemorrhagic septicemia virus, calcium hypochlorite, disinfectant efficacy

\section{Introduction}

Viral hemorrhagic septicemia virus (VHSV) is the causative agent of a devastating disease of finfish, viral hemorrhagic septicemia (VHS). VHSV is a single-stranded ribonucleic acid (ssRNA) virus belonging to the genus Novirhabdovirus from the Family Rhabdoviridae. ${ }^{1,2)}$ Originally described in European Rainbow Trout Oncorhynchus mykiss, ${ }^{3)}$ the known host and geographic range of VHSV have expanded significantly over the past 30 years. ${ }^{4)}$ Currently, VHSV has been isolated from 82 fish species worldwide, including five cyprinid species. $^{5)}$

In North America, reports of VHSV infection to date have been confined to populations of wild fish. However, the possibility of VHSV spreading to cultured fish remains and has the potential to be devastating given the high susceptibility of some cultured species and the high density of fish in

Corresponding author: DVM, MPH, PhD, College of Veterinary Medicine, Gyeongsang National University, 900 Gajwadong, Chinju 660-701, Korea, Tel: +82-55-772-2352, Fax: +82-55-772-2308, E-mail: hujang@gnu.ac.kr Received: 28 June 2013, Revised: 29 July 2013, Accepted: 5 August 2013 
culture. ${ }^{3)}$ Also, VHSV in Far Eastern Asia could be an indigenous virus in Korean and Japanese coastal area.")

In Korea, VHSV was not detected before 2000, but in 2001, VHSV infection occurred in juveniles of farmed olive flounder (Paralichthys olivaceus) at Pohang, in eastern Korea. ${ }^{7)}$ Thereafter, more widespread VHS outbreaks occurred in Korean olive flounder farms, ${ }^{8)}$ with VHS becoming an endemic problem in the Korean aquaculture industry. Furthermore, VHSV has been detected from wild marine fishes in Korean coastal areas. ${ }^{9)}$

With the respect to human health associated with VHSV, it cannot infect humans even if they eat fish with the virus. However, it is generally recommended as a precaution thoroughly to cook all fish due to parasites and bacteria. ${ }^{10,11)}$

Water supplies for seed production and aquaculture often provide an efficient means for the introduction and spread of infectious diseases. A pathogen-free water source is essential for success in aquaculture. Surface waters commonly used in aquaculture come from coastal waters or rivers and may contain some fish pathogens, and such open water supplies should not be used without treatment. Disinfection of wastewater before discharging is necessary to avoid the pathogen contamination to the environment. $^{12)}$

Kurita et al. (2002) reported that 1-propanol, cresol, choline and iodophor were inactivated VHSV, ${ }^{13)}$ whereas methanol, ethanol and phenol had fewer activities. In the previous study, ${ }^{14)}$ treatments with isopropyl alcohol, mineral oil, salt and borax, were effective in inactivating VHSV.

Many disinfectants such as iodophore, sodium hypochlorite solution, benzalconium chloride solution, saponated cresole solution, formaldehyde solution, and potassium pennanganate solution, were reported to have a virucidal activity against various fish pathogenic viruses. ${ }^{15)}$

In the previous studies, ${ }^{16,17)}$ calcium hypochlorite was sufficient to inactivate the herpes-like virus during a 15-min exposure and red sea bream iridovirus during a 30-min exposure. However, there is not the efficacy test for the disinfectant composed of calcium hypochlorite $\left(\mathrm{Ca}(\mathrm{ClO})_{2}\right)$ against VHSV. Therefore, this study was carried out to examine virucidal efficacy of the disinfectant tablet against VHSV.

\section{Materials and Methods}

\section{Disinfectant}

The active ingredients for Easy-Wash ${ }^{\circledR}$, the tested disinfectant tablet, are calcium hypochlorite $(70 \% \mathrm{w} / \mathrm{w})$. Easy-Wash ${ }^{\circledR}$ was provided by Dae Han New Pharm Co. (Seoul, Korea) The disinfectant tablet was stored in the dark in room temperature and prepared for dilution on the day of evaluation. Determination of the antiviral efficacy of the disinfectant was based on Animal and Plant Quarantine Agency (APQA) Regulation No. 2013-34, Korea. ${ }^{18)}$

\section{VHSV and culture}

Viral hemorrhagic septicemia virus (VHSV-Yeosu 05 strain, VHSV) obtained from the College of Fisheries and Ocean Sciences, Chonnam National University (Yeosu, Korea). The VHSV was inoculated in fat head minnow (FHM) cell line and cultured in Eagle's minimum essential medium (MEM, Gibco, Germany) containing 10\% fetal bovine serum, $100 \mathrm{IU} / \mathrm{ml}$ penicillin $\mathrm{G}$ and $100 \mu \mathrm{g} / \mathrm{ml}$ streptomycin sulfate at $20^{\circ} \mathrm{C}$ for $4-5$ days. After virus growth, infected cells were frozen and thawed three times followed by centrifugation at $400 \times \mathrm{g}$ for 20 min to remove cell debris. The initial viral titer was $1.2 \times 10^{7}$ tissue culture infecting dose (TCID) $)_{50} / \mathrm{ml}$. All virus stocks were stored in small aliquots at $4 \mathrm{C}$ until used.

\section{Diluents and treatment condition}

Testing was based on virucidal effects of disinfectant diluents in three treatment conditions (distilled water (DW) condition, standard hard water (HW) condition, and organic matter (OM) condition), pathogen control (disinfectant negative control) and DW control (both disinfectant and pathogen negative control) in Table 1 . HW, an ingredient of $\mathrm{HW}$ treatment condition, was made by adding anhydrous $\mathrm{CaCl}_{2} \quad 0.305 \mathrm{~g}$ and $\mathrm{MgCl}_{2} \cdot 6 \mathrm{H}_{2} \mathrm{O} \quad 0.139 \mathrm{~g}$ into 1 liter distilled water. Organic suspension, an ingredient of $\mathrm{OM}$ treatment condition, is a solution of $1 \%(\mathrm{w} / \mathrm{v})$ fetal bovine serum (FBS, Sigma-Aldrich Korea, Seoul) in HW.

\section{Virus-disinfectant contact reaction}

An aquatic disinfectant tablet (Easy-Wash ${ }^{\circledR}$ ) was diluted 18,000, 20,000, 22,000, 24,000, 26,000, and 
Table 1. Experimental design for the determination of the virucidal efficacy of an aquatic disinfectant tablet

\begin{tabular}{cccccc}
\hline \hline \multirow{2}{*}{$\begin{array}{c}\text { Treatment } \\
\text { condition }\end{array}$} & \multicolumn{5}{c}{ Contents according to treatment condition } \\
\cline { 2 - 6 } & DW & HW & OM & Disinfectant & VHSV \\
\hline DW condition & + & - & - & + & + \\
HW condition & - & + & - & + & + \\
OM condition & - & - & + & + & + \\
$\begin{array}{c}\text { Pathogen } \\
\text { control }\end{array}$ & - & + & - & - & + \\
DW control & + & - & - & - & + \\
\hline
\end{tabular}

*DW, distilled water; HW, standard hard water; OM, organic matter; VHSV, viral hemorrhagic septicemia virus.

${ }^{\dagger}+$, presence; -, absence.

28,000 times with DW, and diluted 16,000, 18,000, 20,000, 22,000, 24,000, and 26,000 times with HW, and diluted 12,000, 14,000, 16,000, 18,000, 20,000, and 22,000 times with $\mathrm{OM}$, respectively. After dilution of disinfectant, $2.5 \mathrm{ml}$ of disinfectant diluents was added into each test tube.

One $\mathrm{ml}$ of VHSV stock was diluted with $19 \mathrm{ml}$ DW, HW, and OM, respectively. After dilution of the viral stock, $2.5 \mathrm{ml}$ of the diluents was inserted into each test tube containing disinfectant diluents, and incubated at $4^{\circ} \mathrm{C}$ for $30 \mathrm{~min}$.

\section{Evaluation of Easy-Wash against HVSV}

After virus-disinfectant contact reaction, $2.5 \mathrm{ml}$ of $10 \%$ inactivated fetal bovine serum was added into each test tube to neutralize efficacy of disinfectant at room temperature. The neutralized solutions were diluted $10,10^{2}, 10^{3}, 10^{4}, 10^{5}$, and $10^{6}$ times with MEM medium containing $10 \%$ fetal bovine serum and $50 \mu \mathrm{l}$ of the neutralized

Table 2. The validation of an aquatic disinfectant tablet against viral hemorrhagic septicemia virus: first examination

\begin{tabular}{|c|c|c|c|c|c|c|c|c|c|}
\hline \multirow{2}{*}{$\begin{array}{l}\text { Tratment } \\
\text { condition* }\end{array}$} & \multirow{2}{*}{$\begin{array}{l}\text { Dilution } \\
\text { time }\end{array}$} & \multicolumn{6}{|c|}{ Dilution time of neutralization solution (positive/the number of inoculation) } & \multirow{2}{*}{$\mathrm{TCID}_{50}^{\dagger}$} & \multirow{2}{*}{$\begin{array}{l}\text { Log } \\
\text { reduction }\end{array}$} \\
\hline & & $10^{-1}$ & $10^{-2}$ & $10^{-3}$ & $10^{-4}$ & $10^{-5}$ & $10^{-6}$ & & \\
\hline \multirow{6}{*}{ DW } & 18,000 & $0 / 5$ & $0 / 5$ & $0 / 5$ & $0 / 5$ & $0 / 5$ & $0 / 5$ & $\leq 0.5$ & $\geq 5.3$ \\
\hline & 20,000 & $0 / 5$ & $0 / 5$ & $0 / 5$ & $0 / 5$ & $0 / 5$ & $0 / 5$ & $\leq 0.5$ & $\geq 5.3$ \\
\hline & 22,000 & $4 / 5$ & $2 / 5$ & $1 / 5$ & $0 / 5$ & $0 / 5$ & $0 / 5$ & 0.9 & 4.4 \\
\hline & 24,000 & $4 / 5$ & $3 / 5$ & $1 / 5$ & $0 / 5$ & $0 / 5$ & $0 / 5$ & 1.1 & 4.2 \\
\hline & 26,000 & $5 / 5$ & $5 / 5$ & $2 / 5$ & $1 / 5$ & $0 / 5$ & $0 / 5$ & 2.1 & 3.2 \\
\hline & 28,000 & $5 / 5$ & $5 / 5$ & $4 / 5$ & $3 / 5$ & $2 / 5$ & $1 / 5$ & 3.5 & 1.8 \\
\hline \multirow{6}{*}{ HW } & 16,000 & $0 / 5$ & $0 / 5$ & $0 / 5$ & $0 / 5$ & $0 / 5$ & $0 / 5$ & $\leq 0.5$ & $\geq 5.3$ \\
\hline & 18,000 & $4 / 5$ & $2 / 5$ & $1 / 5$ & $0 / 5$ & $0 / 5$ & $0 / 5$ & 0.9 & $\geq 5.3$ \\
\hline & 20,000 & $5 / 5$ & $2 / 5$ & $1 / 5$ & $0 / 5$ & $0 / 5$ & $0 / 5$ & 1.1 & 4.2 \\
\hline & 22,000 & $5 / 5$ & $4 / 5$ & $2 / 5$ & $1 / 5$ & $0 / 5$ & $0 / 5$ & 1.9 & 3.0 \\
\hline & 24,000 & $5 / 5$ & $5 / 5$ & $3 / 5$ & $1 / 5$ & $0 / 5$ & $0 / 5$ & 2.3 & 2.2 \\
\hline & 26,000 & $5 / 5$ & $5 / 5$ & $4 / 5$ & $1 / 5$ & $0 / 5$ & $0 / 5$ & 2.5 & 1.4 \\
\hline \multirow{6}{*}{$\mathrm{OM}$} & 12,000 & $0 / 5$ & $0 / 5$ & $0 / 5$ & $0 / 5$ & $0 / 5$ & $0 / 5$ & $\leq 0.5$ & $\geq 5.3$ \\
\hline & 14,000 & $0 / 5$ & $0 / 5$ & $0 / 5$ & $0 / 5$ & $0 / 5$ & $0 / 5$ & $\leq 0.5$ & $\geq 5.3$ \\
\hline & 16,000 & $4 / 5$ & $3 / 5$ & $1 / 5$ & $0 / 5$ & $0 / 5$ & $0 / 5$ & 1.1 & 4.2 \\
\hline & 18,000 & $5 / 5$ & $4 / 5$ & $1 / 5$ & $0 / 5$ & $0 / 5$ & $0 / 5$ & 1.5 & 3.2 \\
\hline & 20,000 & $5 / 5$ & $5 / 5$ & $2 / 5$ & $1 / 5$ & $0 / 5$ & $0 / 5$ & 2.1 & 2.4 \\
\hline & 22,000 & $5 / 5$ & $5 / 5$ & $4 / 5$ & $1 / 5$ & $0 / 5$ & $0 / 5$ & 2.5 & 1.8 \\
\hline $\begin{array}{c}\text { Pathogen } \\
\text { control }\end{array}$ & & $5 / 5$ & $5 / 5$ & $5 / 5$ & $5 / 5$ & $5 / 5$ & $4 / 5$ & 5.3 & \\
\hline DW control & & $5 / 5$ & $5 / 5$ & $5 / 5$ & $5 / 5$ & $5 / 5$ & $3 / 5$ & 5.1 & \\
\hline
\end{tabular}

"DW, distilled water; HW, hard water; OM, organic matter.

${ }^{\top} \mathrm{TCID}_{50}=-\mathrm{L} 1-[\mathrm{L} \times\{\mathrm{S} / 100-0.5\}]$

$\left(\mathrm{L}_{1}, \log\right.$ of lowest dilution tested; $\mathrm{L}, \log$ interval between dilutions; $\mathrm{S}$, sum of $\%$ mortality at each dilution). 
Table 3. The validation of an aquatic disinfectant tablet against viral hemorrhagic septicemia virus: second examination

\begin{tabular}{|c|c|c|c|c|c|c|c|c|c|}
\hline \multirow{2}{*}{$\begin{array}{l}\text { Tratment } \\
\text { condition }\end{array}$} & \multirow{2}{*}{$\begin{array}{l}\text { Dilution } \\
\text { time }\end{array}$} & \multicolumn{6}{|c|}{ Dilution time of neutralization solution (positive/the number of inoculation) } & \multirow{2}{*}{$\mathrm{TCID}_{50}^{\dagger}$} & \multirow{2}{*}{$\begin{array}{c}\text { Log } \\
\text { reduction }\end{array}$} \\
\hline & & $10^{-1}$ & $10^{-2}$ & $10^{-3}$ & $10^{-4}$ & $10^{-5}$ & $10^{-6}$ & & \\
\hline \multirow{6}{*}{ DW } & 18,000 & $0 / 5$ & $0 / 5$ & $0 / 5$ & $0 / 5$ & $0 / 5$ & $0 / 5$ & $\leq 0.5$ & $\geq 5.3$ \\
\hline & 20,000 & $0 / 5$ & $0 / 5$ & $0 / 5$ & $0 / 5$ & $0 / 5$ & $0 / 5$ & $\leq 0.5$ & $\geq 5.3$ \\
\hline & 22,000 & $4 / 5$ & $3 / 5$ & $1 / 5$ & $0 / 5$ & $0 / 5$ & $0 / 5$ & 1.1 & 4.2 \\
\hline & 24,000 & $5 / 5$ & $3 / 5$ & $2 / 5$ & $0 / 5$ & $0 / 5$ & $0 / 5$ & 1.5 & 3.8 \\
\hline & 26,000 & $5 / 5$ & $4 / 5$ & $3 / 5$ & $1 / 5$ & $0 / 5$ & $0 / 5$ & 2.1 & 3.2 \\
\hline & 28,000 & $5 / 5$ & $5 / 5$ & $4 / 5$ & $3 / 5$ & $1 / 5$ & $0 / 5$ & 3.1 & 2.2 \\
\hline \multirow{6}{*}{ HW } & 16,000 & $0 / 5$ & $0 / 5$ & $0 / 5$ & $0 / 5$ & $0 / 5$ & $0 / 5$ & $\leq 0.5$ & $\geq 5.3$ \\
\hline & 18,000 & $4 / 5$ & $2 / 5$ & $1 / 5$ & $0 / 5$ & $0 / 5$ & $0 / 5$ & 0.9 & 4.4 \\
\hline & 20,000 & $4 / 5$ & $3 / 5$ & $1 / 5$ & $0 / 5$ & $0 / 5$ & $0 / 5$ & 1.1 & 4.2 \\
\hline & 22,000 & $5 / 5$ & $4 / 5$ & $2 / 5$ & $1 / 5$ & $0 / 5$ & $0 / 5$ & 1.9 & 3.4 \\
\hline & 24,000 & $5 / 5$ & $5 / 5$ & $3 / 5$ & $2 / 5$ & $1 / 5$ & $0 / 5$ & 2.7 & 2.6 \\
\hline & 26,000 & $5 / 5$ & $5 / 5$ & $5 / 5$ & $4 / 5$ & $2 / 5$ & $1 / 5$ & 3.9 & 1.4 \\
\hline \multirow{6}{*}{$\mathrm{OM}$} & 12,000 & $0 / 5$ & $0 / 5$ & $0 / 5$ & $0 / 5$ & $0 / 5$ & $0 / 5$ & $\leq 0.5$ & $\geq 5.3$ \\
\hline & 14,000 & $4 / 5$ & $3 / 5$ & $1 / 5$ & $0 / 5$ & $0 / 5$ & $0 / 5$ & 1.1 & 4.2 \\
\hline & 16,000 & $5 / 5$ & $5 / 5$ & $2 / 5$ & $1 / 5$ & $0 / 5$ & $0 / 5$ & 2.1 & 3.2 \\
\hline & 18,000 & $5 / 5$ & $5 / 5$ & $4 / 5$ & $2 / 5$ & $1 / 5$ & $0 / 5$ & 2.9 & 2.4 \\
\hline & 20,000 & $5 / 5$ & $5 / 5$ & $5 / 5$ & $3 / 5$ & $1 / 5$ & $0 / 5$ & 3.3 & 2.0 \\
\hline & 22,000 & $5 / 5$ & $5 / 5$ & $5 / 5$ & $4 / 5$ & $3 / 5$ & $1 / 5$ & 4.1 & 1.2 \\
\hline $\begin{array}{c}\text { Pathogen } \\
\text { control }\end{array}$ & & $5 / 5$ & $5 / 5$ & $5 / 5$ & $5 / 5$ & $5 / 5$ & $4 / 5$ & 5.3 & \\
\hline DW control & & $5 / 5$ & $5 / 5$ & $5 / 5$ & $5 / 5$ & $5 / 5$ & $4 / 5$ & 5.3 & \\
\hline
\end{tabular}

"DW, distilled water; HW, hard water; OM, organic matter.

${ }^{\mathrm{T}} \mathrm{TCID}_{50}=-\mathrm{L} 1-[\mathrm{L} \times\{\mathrm{S} / 100-0.5\}]$

$\left(\mathrm{L}_{1}, \mathrm{Log}\right.$ of lowest dilution tested; $\mathrm{L}, \log$ interval between dilutions; $\mathrm{S}$, sum of $\%$ mortality at each dilution).

solution diluents each was injected into five well of FHM cells cultured 96-well plate. After inoculation, the cultures were incubated for 5 days at $37^{\circ} \mathrm{C}$ with relative humidity at $85 \%$. The appearance of viral cytopathic effect (CPE) was checked with a microscope everyday during the incubation period.

The validity of concentration for the disinfectant was calculated as the concentration of the dilution that the viral dose in the cell stock treated with Easy-Wash ${ }^{\circledR}$ was inactivated more than $10^{4}$ tissue culture infectious dose $\left(\mathrm{TCID}_{50}\right)$ compared with positive control. TCID $_{50}$ was calculated according to the method of Käber. $^{19)}$ The validity of concentration for an aquatic disinfectant tablet was independently examined on triplicate and determined the validity of concentration with the median of the results.

\section{Results}

Tables 2-4 present the results of the efficacy testing of an aquatic disinfectant tablet composed to calcium hypochlorite against VHSV. Table 5 shows the summary of the valid dilution time for an aquatic disinfectant tablet against VHSV. On DW and HW condition, VHSV was inactivated with 24,000 and 20,000 fold dilutions of the disinfectant throughout all experiments, respectively. With the investigation of the antiviral effect of the disinfectant on OM condition, VHSV was inactivated on 16,000 fold dilutions.

As organic material interferes with efficacy by either inactivating the disinfectant or blocking it from surface contact, the virucidal activity of an aquatic disinfectant tablet on the OM condition lowered efficacy against VHSV compared with DM or HW conditions. ${ }^{17)}$

J Environ Health Sci 2013: 39(4): 376-382 
Table 4. The validation of an aquatic disinfectant tablet against viral hemorrhagic septicemia virus: third examination

\begin{tabular}{|c|c|c|c|c|c|c|c|c|c|}
\hline \multirow{2}{*}{$\begin{array}{l}\text { Tratment } \\
\text { condition }\end{array}$} & \multirow{2}{*}{$\begin{array}{l}\text { Dilution } \\
\text { time }\end{array}$} & \multicolumn{6}{|c|}{ Dilution time of neutralization solution (positive/the number of inoculation) } & \multirow{2}{*}{$\mathrm{TCID}_{50}^{\dagger}$} & \multirow{2}{*}{$\begin{array}{c}\text { Log } \\
\text { reduction }\end{array}$} \\
\hline & & $10^{-1}$ & $10^{-2}$ & $10^{-3}$ & $10^{-4}$ & $10^{-5}$ & $10^{-6}$ & & \\
\hline \multirow{6}{*}{ DW } & 18,000 & $0 / 5$ & $0 / 5$ & $0 / 5$ & $0 / 5$ & $0 / 5$ & $0 / 5$ & $\leq 0.5$ & $\geq 5.3$ \\
\hline & 20,000 & $0 / 5$ & $0 / 5$ & $0 / 5$ & $0 / 5$ & $0 / 5$ & $0 / 5$ & $\leq 0.5$ & $\geq 5.3$ \\
\hline & 22,000 & $4 / 5$ & $2 / 5$ & $1 / 5$ & $0 / 5$ & $0 / 5$ & $0 / 5$ & 0.9 & 4.4 \\
\hline & 24,000 & $4 / 5$ & $3 / 5$ & $1 / 5$ & $0 / 5$ & $0 / 5$ & $0 / 5$ & 1.1 & 4.2 \\
\hline & 26,000 & $5 / 5$ & $4 / 5$ & $3 / 5$ & $2 / 5$ & $1 / 5$ & $0 / 5$ & 2.5 & 2.9 \\
\hline & 28,000 & $5 / 5$ & $5 / 5$ & $5 / 5$ & $4 / 5$ & $2 / 5$ & $1 / 5$ & 3.9 & 1.4 \\
\hline \multirow{6}{*}{ HW } & 16,000 & $0 / 5$ & $0 / 5$ & $0 / 5$ & $0 / 5$ & $0 / 5$ & $0 / 5$ & $\leq 0.5$ & $\geq 5.3$ \\
\hline & 18,000 & $0 / 5$ & $0 / 5$ & $0 / 5$ & $0 / 5$ & $0 / 5$ & $0 / 5$ & $\leq 0.5$ & $\geq 5.3$ \\
\hline & 20,000 & $4 / 5$ & $3 / 5$ & $1 / 5$ & $0 / 5$ & $0 / 5$ & $0 / 5$ & 1.1 & 4.2 \\
\hline & 22,000 & $5 / 5$ & $4 / 5$ & $3 / 5$ & $1 / 5$ & $0 / 5$ & $0 / 5$ & 3.1 & 2.2 \\
\hline & 24,000 & $5 / 5$ & $5 / 5$ & $4 / 5$ & $2 / 5$ & $1 / 5$ & $0 / 5$ & 3.9 & 2.4 \\
\hline & 26,000 & $5 / 5$ & $5 / 5$ & $5 / 5$ & $4 / 5$ & $3 / 5$ & $1 / 5$ & 4.3 & 1.0 \\
\hline \multirow{6}{*}{$\mathrm{OM}$} & 12,000 & $0 / 5$ & $0 / 5$ & $0 / 5$ & $0 / 5$ & $0 / 5$ & $0 / 5$ & $\leq 0.5$ & $\geq 5.3$ \\
\hline & 14,000 & $0 / 5$ & $0 / 5$ & $0 / 5$ & $0 / 5$ & $0 / 5$ & $0 / 5$ & $\leq 0.5$ & $\geq 5.3$ \\
\hline & 16,000 & $4 / 5$ & $3 / 5$ & $1 / 5$ & $0 / 5$ & $0 / 5$ & $0 / 5$ & 1.1 & 4.2 \\
\hline & 18,000 & $5 / 5$ & $4 / 5$ & $3 / 5$ & $1 / 5$ & $0 / 5$ & $0 / 5$ & 2.1 & 3.2 \\
\hline & 20,000 & $5 / 5$ & $5 / 5$ & $4 / 5$ & $3 / 5$ & $1 / 5$ & $0 / 5$ & 3.1 & 2.2 \\
\hline & 22,000 & $5 / 5$ & $5 / 5$ & $5 / 5$ & $4 / 5$ & $3 / 5$ & $2 / 5$ & 4.3 & 1.0 \\
\hline $\begin{array}{l}\text { Pathogen } \\
\text { control }\end{array}$ & & $5 / 5$ & $5 / 5$ & $5 / 5$ & $5 / 5$ & $5 / 5$ & $4 / 5$ & 5.3 & \\
\hline DW control & & $5 / 5$ & $5 / 5$ & $5 / 5$ & $5 / 5$ & $5 / 5$ & $3 / 5$ & 5.1 & \\
\hline
\end{tabular}

"DW, distilled water; HW, hard water; OM, organic matter.

${ }^{\top} \mathrm{TCID}_{50}=-\mathrm{L} 1-[\mathrm{L} \times\{\mathrm{S} / 100-0.5\}]$

$\left(\mathrm{L}_{1}, \log\right.$ of lowest dilution tested; $\mathrm{L}, \log$ interval between dilutions; $\mathrm{S}$, sum of $\%$ mortality at each dilution).

Table 5. The summary of the valid dilution time for an aquatic disinfectant tablet against viral hemorrhagic septicemia virus

\begin{tabular}{ccccc}
\hline \hline \multirow{2}{*}{ Tretment condition* } & \multicolumn{3}{c}{ Experiment } & \multirow{2}{*}{ Median } \\
\cline { 2 - 4 } & first & second & third & $1 / 24,000$ \\
DW & $1 / 24,000$ & $1 / 22,000$ & $1 / 24,000$ & $1 / 20,000$ \\
HW & $1 / 20,000$ & $1 / 20,000$ & $1 / 20,000$ & $1 / 16,000$ \\
OM & $1 / 16,000$ & $1 / 14,000$ & $1 / 16,000$ & \\
Pathogen control $\left(\mathrm{TCID}_{50} / \mathrm{ml}\right)$ & 5.3 & 53 & 5.3 & \\
DW control $\left(\mathrm{TCID}_{50} / \mathrm{ml}\right)$ & 5.1 & 5.3 & 5.1 & \\
\hline
\end{tabular}

${ }^{*} \mathrm{DW}$, distilled water; HW, hard water; OM, organic matter.

\section{Discussion}

Viral hemorrhagic septicemia virus (VHSV) is a serious fish pathogen that has been responsible for large-scale fish kills in all over the world. ${ }^{20)}$ To prevent the occurrence of VHSV, all facilities, associated equipment and water should disinfect with suitable and effective disinfectants.

According to the study of Ahne (1982), ${ }^{21)}$ chemicals regularly used for water treatment in connection with parasite and fungus infections as methylene blue, malachite green, benzalkonium chloride, and copper sulphate had no effect on VHSV. However, Kurita et al. (2002) demonstrated that the minimum effective 
concentration of a $10 \%$ benzalkonium chloride and iodophor product for VHSV disinfection was 1:1,000 at $30 \mathrm{~min}$ and 1:20,000 at $1 \mathrm{~min}$ exposure, respectively. And $40 \%$ of both methanol and ethanol had no effect on VHSV, whereas propanol was effective disinfecting VHSV within $30 \mathrm{sec}$ in a $30 \%$ concentration. ${ }^{22)}$ In addition, Jørgensen (1973) reported that 2-3\% formalin solution inactivated VHSV within 5 min. $^{23)}$ Furthermore, Ahne (1982) reported that VHSV was inactivated by Actomar (100 ppm $\left.\mathrm{I}_{2}\right), 3 \%$ formalin, and $2 \% \mathrm{NaOH}$, but not by methylene blue, malachite green, mefarol, or $\mathrm{CuSO}_{4}{ }^{24)}$

Due to the economic and reliable disinfect, formalin has been widely used as a disinfectant for decontamination of cultured marine fish and its facilities. However, formalin had to be replaced in many countries including France because of its potential carcinogenic effects for human health and environmental concerns. ${ }^{23)}$ In the present study, the disinfectant efficacy of an aquatic disinfectant tablet, an alternative to formalin, against VHSV showed higher than that of the previous studies.

\section{Conclusion}

From the results of the present study, VHSV on DW and HW condition was inactivated with 24,000 and 20,000 fold dilutions of an aquatic disinfectant tablet composed to calcium hypochlorite, respectively. On OM condition, VHSV was inactivated on 16,000 fold dilutions of an aquatic disinfectant tablet. The results showed that the aquatic disinfectant tablet was very effective disinfectant against VHSV compared with $10 \%$ benzalkonium chloride, iodophor, $30 \%$ propanol, and $3 \%$ formalin.

In this study, the efficacy of an aquatic disinfectant tablet has a limitation that the results are based on in vitro test. Organic material in suspension (OM condition) could not represent all possible parameters of VHSV contaminated environments.

As the efficacy of an aquatic disinfectant tablet against VHSV was investigated in vitro, a controlled field trial is required to determine whether the use of an aquatic disinfectant tablet will be able to reduce VHSV in cultured marine fish farm.

\section{Acknowledgement}

This work was financially supported by Dae Han
New Pharm Co., LTD. (Seoul, Korea).

\section{References}

1. Trdo N, Benmansour A, Calisher C, Dietzgen RG, Fang RX, Jackson AO, et al. Family Rhabdoviridae. In: Fauquet CM, Mayo MA, Maniloff J, Desselberger U., Ball LA. editors. Virus taxonomy: 8th report of the international committee on taxonomy of viruses, London: Elsevier Academic Press; 2005. p.623-644.

2. Kim WS, Jung SJ, Kim JO, Kim DW, Kim JH, Oh MJ. Genetic positioning of Korean viral hemorrhagic septicemia virus (VHSV) from cultured and wild marine fishes. J Fish Pathol. 2011; 24(1): $1-9$.

3. Cornwell ER, Labuda SL, Groocock GH, Getchell RG, Bowser PR. Experimental Infection of Koi Carp with viral hemorrhagic septicemia virus type IVb. J Aquat Anim Health. 2013; 25(1): 36-41.

4. Kim R, Faisal M. Emergence and resurgence of the viral hemorrhagic septicemia virus (Novirhabdovirus, Rhabdoviridae, Mononegavirales). J Adv Res. 2011; 2(1): 9-23.

5. Office International des Epizooties (OIE). Viral haemorrhagic septicaemia. In: Aquatic Animal Health Standards Commission editor. Manual of diagnostic tests for aquatic animals, 6th ed. Paris: OIE; 2006. p.279-298.

6. Kim WS, Kim JH, Nishizawa T, Oh MJ. Pathogenicity of viral hemorrhagic septicemia virus (VHSV) isolated from olive flounder Paralichthys olivaceus to masu salmon Oncorhynchus masou. $J$ Fish Pathol. 2012; 25(2): 117-121.

7. Kim SM, Lee JI, Hong MJ, Park HS, Park SI. Genetic relationship of the VHSV (viral hemorrhagic septicemia virus) isolated from cultured olive flounder, Paralichthys olivaceus in Korea. $J$ Fish Pathol. 2003; 16(1): 1-12.

8. Kim WS, Kim SR, Kim DW, Kim JO, Park MA, Kitamura SI, et al. An outbreak of VHSV (viral haemorrhagic septicaemia virus) infection in farmed olive flounder Paralichthys olivaceus in Korea. Aquaculture. 2009; 296(1-2): 165-168.

9. Lee WL, Yun HM, Kim SR, Jung SJ, Oh MJ. Detection of viral haemorrhagic septicaemia virus from marine fish in the South Western coastal area and East China sea. J Fish Pathol. 2007; 20(3): 201-209.

10. Ministry of the Environment Public Information Centre, Ontario. Guide to Eating Ontario Sport Fish 2011-2012. 26th ed. Ontario: Queen's Printer; 
2011. p.14-22.

11. Deardorff TL, Kent ML. Prevalence of larval Anisakis simplex in pen-reared and wild-caught salmon (Salmonidae) from Puget Sound, Washington. J Wildl Dis. 1989; 25(3): 416-419.

12. Kasai H, Yoshimizu M, Ezura Y. Disinfection of water for aquaculture. Fish Sci. 2002; 68(S1): 821824.

13. Kurita J., Iida Y, Nakajima K, Inoue K. Virucidal effects of various disinfectants on viral hemorrhagic septicemia virus (VHSV) isolated from Japanese flounder. Fish Pathol. 2002; 37(4): 175-181.

14. Phelps NBD, Goodwin AE, Marecaux E, Goyal SM. Comparison of treatments to inactivate viral hemorrhagic septicemia virus (VHSV-IVb) in frozen baitfish. Dis Aquat Org. 2013; 102(3): 211216.

15. Yoshmizu M, Yoshinaka T, Hatori S, Hisae Kasal H. Survivability of fish pathogenic viruses in environmental water, and inactivation of fish viruses. Bull Fish Res Agen. 2005; S2: 47-54.

16. Corbeil S, Williams LM, Bergfeld J, Crane MSJ. Abalone herpes virus stability in sea water and susceptibility to chemical disinfectants. Aquaculture, 2012; 326-329; 20-26.

17. Cha CN, Lee YE, Kang IJ, Yoo CY, Park EK, Kim S, et al. Antiviral efficacy of an aquatic disinfectant tablet composed to calcium hypochlorite against red sea bream iridovirus. J Fd Hyg Safety, 2012; 27(3): 285-289.

18. Animal and Plant Quarantine Agency (APQA). The efficacy test guideline for disinfectants: Appendix 3. Protocols for the efficacy test of disinfectants against viruses. APQA Regulation No. 201334. Seoul: APQA; 2008.

19. Kärber G. Beitrag zur kollektiven Behandlung pharmakologischer Reihenversuche. Arch Exp Pathol Pharmakol. 1931; 162(4): 480-487.

20. Mortensen HF, Heuer OE, Lorenzen N, Otte L, Olesen NJ. Isolation of viral haemorrhagic septicaemia virus (VHSV) from wild marine fish species in the Baltic Sea, Kattegat, Skagerrak and the North Sea. Virus Res. 1999; 63(1-2): 95-106.

21. Ahne W. Vergleichende Untersuchung über die Stabilität von vier fischpathogenen Viren (VHSV, PFR, SVCV, IPNV). Zentralbl Veterinarmed B. 1982; 29(6): 457-476.

22. Kurita J, Iida Y, Nakajima K, Inouye K. Virucidal effects of various disinfectants on viral hemorrhagic septicemia virus (VHSV) isolated from Japanese flounder. Fish Pathol. 2002; 37(4): 175-181.

23. Jørgensen PEV. Inactivation of IPN and Egtved virus. Riv It Piscic Ittiop. 1973; 4: 107-108.

24. Ahne W. Studies on the tenacity of fish viruses. Fortschr Veterinaermed. 1982; 35: 305-309. 